\title{
Research on the Reform of English Project Teaching in Higher Vocational Colleges in the New Period
}

\author{
Xurong Xu \\ Yancheng Vocational Institute of Industry Technology, Yancheng, Jiangsu, 224000
}

Keywords: New Era; Vocational English; Project-Based Teaching; Reform

\begin{abstract}
The policy of running higher vocational education is "serving for the purpose, employment-oriented", and cultivating the technical and applied talents needed for the first line of production, construction, service and management. How can English courses in higher vocational colleges reflect the requirements of professional positions for talents and the needs of students' future career development? This is worthy of deep thinking by English teachers in higher vocational colleges. In order to meet the growth and development needs of students, it is necessary to summarize the difficulties faced in the process of teaching reform, to carry out the project-oriented teaching reform of English courses, and then to develop practical solutions. This paper mainly focuses on the above problems, to explore and present the corresponding insights and reflections.
\end{abstract}

\section{Introduction}

With the continuous deepening of English project-oriented teaching reform, more and more vocational English teachers are aware of the inevitability of teaching innovation. Many higher vocational colleges have achieved good results in the process of project-based teaching reform, and English project-oriented teaching reform It is also one of the most important tasks, but in the process it faces various difficulties and obstacles. The author discusses the specificity and proposes the corresponding solutions. Firstly, it analyzes the inevitability of the project-oriented teaching reform of vocational English courses. See below for details.

\section{Investigating the Inevitability of Project-Oriented Teaching Reform in Higher Vocational English Courses}

Project-oriented teaching is an important way to improve the level of English teaching in vocational colleges. In combination with the basic requirements of the English teaching of higher vocational education, English teachers in higher vocational colleges are required to train students to have the ability to use English, have strong listening and speaking skills, and improve their interest in learning. It is difficult to meet the growth and development needs of students by using traditional indoctrination mode. Therefore, students must be motivated to learn, and they should guide students to develop good habits of self-learning, provide students with a new learning experience, and find English knowledge during the learning process. The so-called curriculum project refers to the targeted teaching mode formulated in combination with the basic requirements of the future occupation and related positions for students. The focus of this teaching method is to go deep into the production, management and management, through refining, investigation and analysis, to clarify the specific responsibilities in the position, gradually form a work project, and refer to the process and content to establish a project course. Modules to meet the professional qualification standards, and ultimately build a future career curriculum system [1-3]. This teaching mode can provide direction guidance for teachers' teaching work, so that the teaching content is closely related to the students' future careers and positions, and it is really useful for learning. In this process, students improve their professional quality and increase their knowledge. It can be seen that the reform of curriculum-based teaching in higher vocational colleges is particularly necessary. It aims to combine the teaching objectives, improve the teaching content, optimize the curriculum system, and clarify the future post requirements of students. Based on this, determine the most 
scientific teaching. The direction to improve the learning efficiency of students can also guarantee the quality of teaching.

The project can change the current teaching status of the current English course. At present, higher vocational colleges have more admission channels and more complicated students. There are ordinary high school students who have passed the scores and high-level students who have failed to meet the standards in advance. There are also students in technical secondary schools and technical schools. Therefore, the students' English level is uneven, which brings great difficulties to English teaching.

In the course of English teaching in many higher vocational colleges, students' inefficiency in learning, lack of initiative, and disgusting learning are common problems. It is difficult for teachers to improve their enthusiasm in the teaching process, resulting in students' general resistance, teachers. More teaching work as a task, after completing the teaching materials and teaching objectives, no longer infiltrate the knowledge of learning value, failing to combine the students' growth and learning needs, expand the scope of knowledge, and increase the students' knowledge, resulting in the final The overall quality of students is extremely low, and it is difficult to find a suitable job and realize the value of their lives, which is extremely unfavorable for their growth and development.

In addition, students in higher vocational colleges are in adolescence, they have their own ideas, their personality is extremely flamboyant, and their personality is lively and outgoing. For the traditional indoctrination teaching mode, it will be difficult to improve their enthusiasm for learning, especially for English courses. The boring content and boring grammar, vocabulary, etc., make them less active in learning, resulting in inefficient English learning [4-5]. The curriculum project teaching reform is undoubtedly an important way to improve students' learning efficiency. For the comprehensive reform of the traditional teaching mode, teachers are required to reflect the student's subjective status, and achieve the project teaching objectives under the joint efforts of teachers and students.

\section{The Problems in the Reform Process of Vocational English Courses}

The nature of positioning is not clear. At present, many higher vocational colleges are unable to clarify the tasks and practical methods of teaching reform in the process of carrying out English project-oriented teaching. They have more choices to build cars behind closed doors, fail to combine the needs of social posts, and formulate targeted reform plans. Some institutions regard the English curriculum project teaching as a completely independent public class, and some institutions believe that the focus of reform is to strengthen students' literacy skills, and class A and B as important assessment criteria, as well as some institutions directly Position it as a competency lesson. The above-mentioned higher vocational colleges are extremely vague about the nature of project-based instruction in English courses. The focus is biased. The failure to understand the essence of project-based teaching, inaccurate course positioning, will not guarantee the level of teaching, and it is difficult to improve students' learning efficiency. [6-8].

The teaching and occupation of the course are contrary to the quality requirements of the talents. Many higher vocational colleges will strictly follow the principles of task-driven and project-oriented in the course of project-based teaching of English courses, redesigning teaching plans, formulating new project teaching tasks, and implementing teaching in strict accordance with the designed projects. However, due to the inability to understand the nature of the project in depth, more choices regard the project-based instruction of the English course as a work item, and even think that the project teaching is a situational teaching, resulting in a disconnect between each project, even in a state of separation from each other. It is difficult to reflect the integrity, logic and systemicity of the project-based teaching of English courses.

At present, many higher vocational colleges have actively implemented project-based teaching work, but the research design, teaching planning, goal setting and other aspects, the research strength is seriously insufficient, resulting in a single teaching plan, lack of flexibility, it is difficult to guarantee the English curriculum project teaching quality. In addition, the assessment method 
still uses the traditional closed-volume test, which emphasizes the students' achievements, and the objectiveness of the assessment is insufficient to effectively reflect the students' comprehensive ability.

\section{Measures to Solve the Problem of Project Reform of Higher Vocational English Courses}

As early as the second half of 2012, Shenzhen Vocational and Technical College realized the inevitability of English project-oriented teaching reform, adhering to the principle of cultural education and collaborative education, and committed to the goal of reforming both morality and brains, focusing on cultivating high quality. Highly skilled talents have achieved remarkable results. The author combines the English project-oriented teaching reform work mode implemented by this institution and the preliminary practice of the English project-oriented curriculum reform in this college. It is believed that the following aspects are mainly started.

The requirements of English talents in various social sectors are relatively high, and they also reflect the characteristics of diversification. If you want to meet the needs of skilled talents in various professional fields, you must learn to use public English and start from various industries to define the profession. For example, for trade, hotels, tourism, etc., from different professional needs, determine the content of the lectures, so as to cultivate students' English skills. Do a good job in industry research, or focus on listening and speaking ability development, or focus on improving literacy. Taking the hotel catering industry as an example, the demand for English-skilled talents at the front desk is reflected in the oral expression. It can accept the customer's telephone reservation and can check-in and check-out for the visitors. Therefore, in order to cultivate this type of English talents, it is necessary to combine the job requirements for the professional needs of skilled English talents, formulate the most appropriate teaching objectives, effectively integrate the employment destination and the content learned, and make the teaching plan more service and targeted.

The focus of the project-oriented teaching reform of higher vocational English courses is curriculum design and project development. The curriculum design process requires the combination of social research results and reference analysis results to promote the close relationship between project development and post practice, and more practical and operability. The overall design of the course and the development of the teaching project are not imagined by one person or several people. He needs to conduct an in-depth and objective investigation of the market requirements of this course and the profession. On this basis, careful summarization and sublimation can be made. Therefore, in the course design and project development process, professional English talents need to be employed, actively coordinate and cooperate with relevant enterprises, effectively integrate the internal resources of the school, society and enterprises, form a high-quality R\&D team, and complete the task efficiently. Strengthen the participation of social forces, greatly improve the design ability of the program, and ensure the design level. The team members are composed of double-skilled teachers, backbone teachers and enterprise elites who are proficient in English, ensuring the integrity, accuracy and science of social research and analysis. Sexuality, clarify the needs of professional English talents, innovate teaching models, design distinctive teaching programs, and make project development more in-depth, which will promote the improvement of students' learning efficiency and the long-term development in the future.

In the process of vocational English project teaching, the textbook can be described as extremely important content, which directly affects the teaching direction, and also relates to the quality of teaching. Therefore, the author suggests to do a good job of self-editing project-oriented textbooks, collect books and audio-visual materials, combine existing textbooks, and compile project-based teaching materials according to the requirements of the curriculum system, so that it is more in line with the students' learning rules and satisfy as much as possible. Its growth needs. Not only that, but also need to combine the information of social research, target the optimization of project materials, make the teaching materials more practical, and ensure the students' learning efficiency, so that students can learn interest in the teaching materials, fully mobilize the enthusiasm of learning, in order to create a good Learn the atmosphere and improve the quality of teaching.

For English project-oriented teaching tasks, students should achieve their learning goals in a 
team-based manner. Whether it is organizational form, teaching content or teaching methods, they must break through the traditional teaching mode, reflect the professional advantages of teachers, and communicate with students. Master the students' internal needs, summarize their psychological characteristics, and finally develop their expertise. In this process, the role of teachers has changed in essence, the status of teachers and students has changed, teachers have played a guiding role, and the subject status is students. Through the good cooperation between teachers and students, the teaching objectives of English curriculum projects are gradually achieved, and the process is solved.

\section{Conclusion}

In summary, the reform of English project teaching in higher vocational colleges can be described as extremely complicated work, requiring coordination among all parties, and working together to improve and optimize the project-based teaching model. Actively promote the reform of English project-oriented teaching, gradually realize the reform goals, and encourage teachers, students, enterprises and other aspects to fully participate in it. Based on the results of social research, the project-oriented teaching reform work will be deeper, thus greatly improving students' Learning efficiency, making it more enthusiasm for learning, to achieve its life value after entering the society, long-term, sustainable development. Finally, I hope that the author's analysis and discussion will provide reference for high-level English project teaching staff.

\section{References}

[1] Tong Lei, Wang Wenna. Exploration of Project-oriented English Teaching in Higher Vocational Education—CComment on "Higher Vocational English Projectization Course"[J].News \& Writing, 2017, 14(3):10-10.

[2] Zhu Dongjiang, He Jianyou. Analysis and Thinking on the Status Quo of Local Higher Vocational Tourism English Talents Training in the New Period[J].Journal of Hanjiang Teachers College,2017,37(4):135-138.

[3] Ke Jihong. Application of Task Teaching Method in Higher Vocational Tourism English Classroom Based on Professional Background[J].Journal of Hubei Correspondence University,2014,26(19):135-135,141.

[4] Peng Xingyan, Song Ying, Chen Gangtao, et al. Research on English Teaching in Higher Vocational Colleges under the Background of Economic Development in Huairou Region[J]. Linguistics, 2016, 31(9): 119-120.

[5] Fang Yigui. Requirements and Construction Strategies of Mixed-overversion Teaching Mode for Foreign Language Teachers in Higher Vocational Colleges [J]. Vocational Education Forum, 2016, 41(26): 17-20.

[6] Zhang Zhaoxia. Research on the Construction of Aviation Vocational English WeChat Public Number Teaching Platform Based on Mobile Internet[J].Journal of Hubei Correspondence University,2017,30(12):159-161.

[7] Jiang Caixia, Du Liucheng. Research on the Reform of Integrated Teaching Mode of English Teaching in Higher Vocational Colleges Based on Competence-based [J]. Curriculum Education Research, 2015, 19(27): 101-101, 102.

[8] Hou Xiaoli. An Empirical Study on the Construction and Implementation of English Listening and Speaking Teaching Model Based on "Internet +"[J]. Campus English (early), 2018, 01(8): 60-61. 